\title{
Proverbs in Yorùbá Contemporary Songs
}

Oluwafunminiyi Mabawonku

Federal College of Animal Health \& Production Technology

Ibadan, Nigeria

niyimabs@hotmail.com; niyimabs2@gmail.com

\begin{abstract}
The Proverb is the wisdom of the wise; a terse statement of few words. Proverbs are allegorical as the expressed statement is meant to have by analogy or by extended reference, a general or specific connotation. This study serves as a discursive strategy in the knowledge of proverbial lore and language development as exemplified in the works of the two Yorùbá Contemporary song artists to be considered. This study attempts to explain how proverb usage in the hands of these two song artists serves as critical trajectories as it refracts and reforms the debased social constrictions that have engulfed society. Its usage by these song artists is wrapped up in the communal language to puncture the social constrictions and to x-ray the lived experiences of people in the society.

This study reveals that the use of proverbs as indigenous tattoos has elevated both the language of the song artists to the status of living art of popular communication and their personalities to that of a mystic 'massieur' as there is the need to localize the global issues and globalized the local ones. Doing so would enhance and ensure continuity of the salient aspects of our culture especially the language, which now seems to have lost its potency and rhythm via the social constrictions.
\end{abstract}

Keywords: Proverbs, language development, Yorùbá contemporary song Artists, social constrictions, society.

\section{Introduction: Culture, Tradition and Orality}

Songs permeate every aspect of Yorùbá life as there is nothing the Yorùbá people cannot sing about. The oral art remains the lubricant to Yorùbá life and culture, the engine room to its religion. Just as in other world cultures, 
culture in Yorùbá is also principally oral as it is passed down from one generation to the other. The orality and didactic nature of Yorùbá cultural tradition determine her oral literature through which the continuity and authenticity of her cultural identity are preserved. The oral nature of Yorùbá traditional life gives shape to the literature and culture which in turn map out her cultural identity. Orality dictates the shape of the genres of literature: drama, prose and poetry in that the themes of the genres are drawn largely from the oral tradition while culture is the identity and the binding force of a people in a geographical location having shared ideas and ideals as it embodies society's values and norms which are embossed in the tradition. Culture, therefore, is that complex whole that includes knowledge, belief, art, language, law, morals, customs, and all other capabilities and habits acquired by man as a member of a society. Yorùbá culture is thus wayfarer for its literature and this is enmeshed in its language. Language, therefore, serves as the codification system for a society's culture, the culture being represented and realized largely through its literature. The literature of a society entails its tradition such as legend, folk narratives (riddles, proverbs, epics); societal norms and conducts (iwà àti ìrírí); culture is the big umbrella shading both mythical figures and other religious aspects of the tradition. Songs and chants are also aspects of society's culture. All these put together shape the literature of a society and provide its orality.

Culture is the heritage of a race or a people as handed over by their forebears. In the case of the Yorùbá people, this includes inter alia the festivals, dances, drum ensemble and drumming, folktales, myths and legends, chants and songs. In essence, Yorùbá cultural tradition is both historical and experiential. Culture embodies a society's values and norms which are deeply rooted in tradition. Culture, simply put, is the total of the way of life of the people, which includes tradition that comes alive through their language, art, literature, philosophy, medicine and religion. It is the transmission channel for the understanding of the tradition of society. Commenting on Soyinka's Death and the King's Horseman, Tanure Ojaide posits "culture is used to question European/western ignorance of other people's ways and to criticize the arrogant behavior which causes tragedy for others." It is the definer of a people's literature, a pattern of behavior, means or agency of transmission of ideas, technical knowledge as well as habits, values, modes of behavior and socialization. Tradition is often confused with culture and taken to be a synonym for culture. Tradition, however, is the social aspect of culture, for example, chieftaincy ceremony, naming ceremony, body adornment. Culture

1 Ojaide, Tanure. "Modern African Literature and Cultural Identity." African Studies Review 35.3 (1992): 49. 
in Yorùbá is principally oral as it is passed down from one generation to the other. Yorùbá tradition in this wise can be seen as primarily didactic.

As culture is the transmitting channel of the people's tradition, which is principally oral and didactic, the definition given by B.W. Andah in African Development summarizes the discourse on culture. He posits:

"Culture embraces all the material and non-material expression of people as well as the processes with which the expressions are communicated. It has to do with all the social, ethical, intellectual, scientific, artistic and technological expressions and processes of a people usually ethnically and/ or nationally or super nationally related, and usually living in a geographically contiguous area; what they pass on to their successor and how they are passed on." 2

The orality of Yorùbá traditional life gives shape to the literature and culture which in turn map out her cultural identity. The orality of the cultural life of the people is a repository and a major source of education for the entire people in that through the diverse myths, legends, songs and chants told by the older folks to the young ones, the tradition and cultural heritage of the people are preserved to enhance continuity and authenticity. Songs are verbal manifestations of the people's worldview. They are coded verbal elements used in almost everyday lives. This study attempts to show how songs become a cultural artefact in contemporary Nigerian society as it combines proverb usage in its depiction as an Indigenous tattoo to decimate its stylistic angst in aiding meaning and aestheticism in the songs. This paper, therefore goes further, in defining the Indigenous tattoo as a tool of resolving social conflict and as an arrowhead for contemporary songs. It examines how proverb usage as an Indigenous tattoo is used as a tool in deconstructing and correcting the vices in the society; explains how it serves as a pivot stand and as a 'cleansing oracle' in contemporary society.

In Nigerian society, proverb usage has become an indigenous tattoo, the focal point of some contemporary songs. Like in scripted literature, Nigerian contemporary song Artists has taken their songs beyond mere entertainment. Through their songs, they have attempted to condemn vices in the society with a view to proffer solutions by encouraging the citizens of the country to embrace what is deemed as an acceptable way in the society. A critical look at some of these contemporary songs shows that the song Artists employ some satirical techniques through proverb usage that are laced as indigenous tattoos

2 Andah, B.W. "African Development." Occasional Publications of the Department of Anthropology, University of Ibadan, 1982, 4-5. 
to express their indignation about what they abhor and perceived to be abnormal in the society. These song Artists in their use of satire as a lampoon in the proverb are at ease while expressing their annoyance in songs. They consequently enjoy some freedom of speech which Hugh Tracey opines that "one can say in songs or verses what one could not say in prose without offence." ${ }^{3}$ This work, therefore x-rays the use of proverbs as an indigenous tattoo, a cultural artefact in Contemporary Nigerian songs. The songs examined are 'Isé Olúwa kò ș'éni tó yé', 'My Dear: sisí awélórùn' by Múșilliù Hárúnàİṣhòlá, and 'Ìbà' and 'The truth' by Wàsíu Àyìndé Marshal respectively. Efforts would be made to explore how the selected songwriters have been able to employ the indigenous tattoo to decimate their cultural affinity in establishing their thematic concerns by using the Ronald Paulson (1967) modem.

\section{Proverb usage as dialectics of Literature and Cultural Identity}

Proverb usage abounds in many if not all of the African cultures, and this is the pivot on which the identity of the African man is viewed as a biosphere, the phenomenal being. The preponderance of proverbs in many African cultures and their usage dictates and shape the cultural identity of the African man as well as the literature as it attracts attention to him through the oral art distinctiveness in its language usage, brevity and aptness. As dialectic of cultural lore, in African society, a young person is not expected to make use of proverbs in the presence or gathering of elders but in situations where a proverb is used by the former in the gathering of elders, such is expected to acknowledge the elders by paying obeisance to them for his action. Consequently, it is not out of place to hear phrases and statements like tótó se bi òwe o èyin àgbà (meaning: credence to the elders' adage); enu àgbà ni obì ti ńgbó (meaning: kolanut ripens in the mouth of the elders) and a child that sits with an old man, if he does not chew pepper, he chews kola nut.' This, therefore, makes proverb usage to be the exclusive preserve of the adults.

In literature, oral art has been copiously used by writers not just to mirror the cultural values of the people but more importantly, to showcase and achieve both aesthetic and stylistic effects in their works. To this end, this current research effort examines the desire to explore how the two Yorùbá contemporary song Artists, Múșílíù Hárúnà-İshòlá, and Wàsíù Àyìndé Marshal respectively has deployed the use of the indigenous tattoo to reflect as a tool of satire to detonate the cultural tendencies in the body of their songs

3 Tracey, Hugh. Chopi Musicians: Their Music, Poetry and Instruments. 1974. Quoted in Oyin Ogunba. Literary Art and Literary Creativity in Contemporary Africa. Ife: University of Ife, 1978, 50. 
and how they convey their annoyance towards the ills in the society. Oyin Ogunba in Literary Art and Literary Creativity concludes that "the only area of oral literature which is genuinely fruitful of creativity today is the satire." It can be used as a form of taunt on commenting on political problems, religious hypocrisy, moral decadence, leadership injustices and exploitative tendencies of those in the position of authorities. Its uses address the imbalances or lopsidedness in society. To summarize it all, Ogunba further says, "The literature of a people is integral to the life of the people and usually grows from within." 5 Therefore, the use of satire in the proverb is a potent tool in the analysis of Yorùbá contemporary songs, a piece of oral literature. Suffice it to say that a detailed study of the contemporary songs shows that it is suffused with cultural values in a biosphere of an ever-changing society that characterized human living.

The peculiarity of this work that departs from existing works is that the research effort is rooted in its desire to intervene in 'real world' events as part of a broader struggle alongside or on behalf of the disenfranchised and/or oppressed segments of the society. The research effort is borne out of the desire to address a serious political problem of some sort like a social injustice that needs to be corrected, a major structural or institutional inequality that needs to be challenged, and a hierarchy of power that needs to be levelled. The deployment of a proverb, an indigenous tattoo as the cultural hind leg of the society in the Yorùbá contemporary songs is a radical interdisciplinary form of intellectual and political work that operates both inside and outside the academic settings. This becomes significant as the theoretical framework for the research effort is chiefly concerned with human beings in society and the topical issues it focuses on. The theory itself is a human science.

The major material used in this work comes from written sources. For the Yorùbá contemporary songs Artists, the finished works of the artists in a compact disc is used and consequently analyzed accordingly. It should be mentioned that although the genre has been extensively explored by researchers, most of the previous works on it has not specifically focused on the cultural relevance of the songs in contemporary society or on the prescriptive tenets of the Yorùbá culture that produces the songs which are heavily laced with philosophical witty sayings. This, therefore, differentiates this work from the others as it considers its literariness and cultural relevance in an ever-changing human society in relation to a theory. The aesthetics of the oral genre are expressed in its use of lampoons, neologisms and indigenous statements

4 Oyin Ogunba. Literary Art and Literary Creativity in Contemporary Africa. Ife: University of Ife, 1978, 3.

5 Ibid. 
which are predominant in oral literature and in the Yorùbá culture that produces it. This differentiates it from written literature.

Proverb, a potent tool of oral literature as an indigenous tattoo is essential to the survival and understanding of Cultural identity. A proverb can be used to condemn and achieve societal reformation. As a tool, it is used as a form of humor to mock and or ridicule with the sole aim of correcting the ills or vices in an individual, society or nation. As man is a social being in a biosphere, he is susceptible to change. This change can either be a vice or a feat. In Nigerian society as seen in the Yorùbá contemporary songs, its use as a backlash on political and socio-religious hypocrisy inherent in the society is mirrored as its use bring to limelight issues that are integral to the survival or uplifting of the society from the debased or comatose level it has found itself. Proverb usage, therefore, as a social comment is relevant in Yorùbá contemporary songs in deconstructing the social being.

Adeoti posits, "proverbs are indexes of a people's language, history, literature and culture as they are associated with 'elders' who are deemed to be wise with age and not expected to speak in 'plain' terms." In an attempt to project the socio-cultural realities of life through songs in contemporary society, proverb usage forms a significant part of a verbal collage in Yorùbá contemporary songs. Adeoti says this is so "because proverbs serve as expressions of social realities, cultural practices as well as definer of identities within the social milieu wherein 'man' has found himself." 7 There is, therefore "no aspect of life that escapes the sharp eye of the proverbial, whether private or public." ${ }^{\text {It }}$ is sacrosanct to say that proverb is a communal property and is closely linked to the language of the people. These two concepts, proverb and language have a symbiotic relationship as posited by Mabawonku that "both rely on each other and is an interpretant of one another." What this means is that the beauty of the language comes to the fore through the proverb usage while the proverb used showcases the dynamics and aesthetics inherent in the language delightfully and figuratively. Hence, language preserves proverbs from cultural extinction through constant usage.

Suffice it to say that proverb is often linked with wisdom in talk or utterances as people are regarded as being wise when they lace their statements with proverb. However, proverbs are better understood when presented and treated in the context in which they are used as it emphasizes aptness and

6 Adeoti, Gbemisola. "The Loudness of the 'Unsaid': Proverbs in Selected African Drama.” Legon Journal of the Humanities 30.1 (2019): 83.

7 Ibid

8 Ibid

9 Mabawọnku, 'Funminiyi. "Interplay of Ideology, symbols and culture: A reading of Zulu Sofola’s plays.” Iroro: A Journal of Arts 18.1\&2 (2019): 55. 
effectiveness. Hence, its use by the song Artists is to reinforce position, emphasize a point, and give warning or advice as well as give prominence to the indigenous language which is partly in extinction and the dwindling ethical standards in contemporary society. With this hindsight, M.A.K. Halliday gives credence to the spoken words as he intones, "written language is corpuscular and gains power by its density, whereas spoken language is wavelike and gains power by its intricacy." 10 The intricacies of the spoken words are in the power of culture and language that produces it.

Dumbi Osani sees proverb as:

"An important form of African oral tradition. It is a distinctive aspect of the use of language employed mainly by adults in informal conversations as well as informal speeches at meetings, conferences and other occasions. They are commonly used in various forms of oral literature such as folktales, songs, chants and even drama. The older ones (generation) often have their speech colored with this oral act."11

It is no gainsaying to reiterate it that proverb emanates from the reservoir of ancient wisdom and therefore, have the force of tradition behind it. It may be used to either justify an action or to make a point. It may be used to either justify an action or to make a point. Its usage reflects the role it plays in folk narratives, songs and chants to understand the dynamism of linguistic artistry (which Halliday dubs as being intricate) of the [African] language and culture in projecting life and living in the [African] society.

\section{Yorùbá Contemporary Songs}

Yorùbá contemporary songs are off-shoot of Yorùbá occasional songs which are regarded as 'orin àtìgbàdégbà'. The variants of the occasional songs are fújì, wákà, jùjú and àpàlà. However, these variants have been redefined and repackaged to reflect modernization yet, without losing the rich cultural ethos that produces it! The songs are now rendered in a relatively more high pitched voice and with more modern musical accompaniments. Aside from this, both the lead singer and the retinue of chorus sing the songs while standing as opposed to the traditional form in which the songs are rendered in a sitting position thereby decimating the Yorùbá axiom that 'èsò pèlé $n i$ ijó àgbà' (meaning: the elderly dance is with caution). The standing position

10 Halliday, Michael Alexander.K. On Language and Linguistics, edited by Jonathan Webster, The Collected Works of M.A.K Halliday, vol.3, New York: Continuum, 2003, 132.

11 Osani, Dumbi. "The Aesthetics of Proverbs in Nigerian Fiction: D.O Fagunwa and Chinua Achebe.” Papers in English and Linguistics 9 (2008): 95. 
in which the singers render the song coupled with more modern musical accompaniments and the fast tempo in its mode of delivery enhances its danceable status by both the young and not too old in the society. In addition, the standing position of its delivery model ensures better coordination by the lead singer as $\mathrm{s} /$ he could move around easily during the performance to prompt or gear up the retinue of chorus singers in their act and to properly connect with the audience.

\section{Aesthetics and thrust of Yorùbá Contemporary Songs}

Yorùbá contemporary songs are used to condemn acts of wastefulness and neglect both in the society, the nation and at the home front. The songs are used as ideas for cultural revival, social integration and national development, and, as social commentary. Commenting on the socio-cultural relevance of the songs in foregrounding the Yorùbá rich cultural heritage that produces it, Adeyemi Adegoju refers to the use of the talking drum, a non-verbal semiotic sign as "speech surrogate." 12 Drums are used to disseminate information and reinforce an idea. The message or information may be of two kinds. It may either be to foretell or warn of an intending outbreak or danger that may be consequent upon an inimical act in society. It may also be to praise or celebrate the heroic feat or virtues of somebody in the society. In a threetrack album titled, 'sóyòyò' which comprises of eight songs, Músíliù Hárúnà İshòlá, a contemporary àpàlà music griot, in the track, 'Isé Olúwa kò s'éni tó $y e ́$ ' (meaning: God's deed is beyond comprehension) asserts:

Isé tí kálukú bá mò
Kó t'épá mo
Músilíù o,
Àwà la l'Apàlà gidi
whatever trade/profession one knows
one should continue with it
O, Músílíù
we are the custodian of true Àpàlà music

The 'speaking' and comment of the drum form a linguistic complement as they add to the musical aspects of the song. Ruth Finnegan observes that "drum language, in a simpler form, is a specialized form of expression, understood by many but probably only fully mastered and appreciated by the few...

12 Adegoju, Adeyemi. “The Musician as Archivist: An Example of Nigeria's Lagbaja." Itupale: Online Journal of African Studies 1 (2009): 1. 
it is a sign, a signal code." ${ }^{\prime 3}$ More importantly, drum language in nature is often poetical and it adds to the verbal resources of the language. It is worthy to mention that the particular importance of drum language for mankind is that it vastly enhances the definition of meanings and purposes by which all members of a community share and remember an organized pattern of life.

After the interpolation of the drum, the lead singer declares that the skill of singing Àpàlà song is an innate thing in which he requires no formal tutelage as he has been in it for a while:

Àpàlà gidi là wa ńje

Ó ti rò wá lórùn bi èko

Ó ti pé ònà ti jìn

Ó ti rò wá lórùn bi èko

Bí ẹ bá fé s'eré Àpàlà

E kó 'ra yín papò

Kí ẹ mí a bò o

Ki e f'arabalè wá

k’ósé odún méta ò e

we 'eats' the genuine Àpàlà

It is convenient for us like the steamed corn pudding

It's been long as the journey is far

It is convenient for us like the steamed corn pudding

If you want to sing and play Àpàlà

Gather yourselves together

And come along

And be patience

To learn the vocation for three years.

From the lines above, the singer lampoons his rival by proudly declaring that his skill is unparalleled, natural and divinely inspired. He admonishes his rival that to have a good mastery of the art, they should turn to him for tutelage and be properly trained! It should be mentioned that there is extensive use of proverbs in Yorùbá contemporary songs as Yorùbá people are known to always lace their speeches and assertions with witty statements/phrases that are proverbial. As a pointer to his being versed in the trade and have a thorough mastery of his art, an excerpt from Wàsíù Àyìndé Marshal, a contemporary fújì music griot, in his track, 'ibà' from the album titled "Talazo" says:

Àyìndé $t i$ gbése rè dé

13 Finnegan, Ruth. Oral Literature in Africa. Oxford: Clarendon Press, 1970, 498. 
Eq wo b’óse ńpèdè

Bí ęni j'iyò

(Àyìndé has come with his ways

Look at how he uses language

Like one that eats salt).

Salt, which is a condiment for cooking becomes an index for sharpness which enables the song Artist to use the language flawlessly!

A lot is said and revealed in witty statements. An example is depicted in the lyrics above through the lines:

Àpàlà gidi la wa ńje

Ó ti rò wá lórùn bi èko

We 'eats' the genuine Àpàlà,

it is convenient for us like the steamed corn pudding.

and:

Ecwo b’óse ńpèdè

Bí ęni j'iyò

(Look at how he uses language

Like one that eats salt).

The use of an instrumentality of satire through lampoon as expressed proverbially in Yorùbá contemporary songs is to x-ray social ills orchestrated by strife and envy in the society. The lampoon is used to correct the vices. This is achieved through proverbial declaration /witty assertion as exemplified in the lines below in the songs by the two musicians. First, Músíliù Hárúnà Ìshòlá declares:

A kil s'ęgé won ninú orin

A kil s'ęgbé won nínú ilé odù

Eqú olóko àwa ni wón jé!

B'ójé ki á korin

İshòlá ni Baba ò e

we're not their mates in singing

we're not their mates in the house of the riddle

they're slaves unto us in our farms (vocation)!

if it is to sing

$\mathrm{O}$, Ishola is the father

And Wàsíù Àyìndé Marshal retorts: 


\author{
Ęni t'ójù mí lo \\ Ìbà ni mo se o \\ Ìbà fún Barrister \\ Ìbà fún Kollington \\ T'ómodé bá ti júbà àgbà \\ Ó dájú kò ní k’ọşè
}

Those who're older than me

O, I pay homage

I pay homage to Barrister

I pay homage to Kollington

when a child pays homage to the elders

such will not suffer misguide.

As against Músílíu Hárúnà Ìshòlá whose detractors are not willing or ready to acknowledge which thus results in his casting satiric aspersions on them via the lyrics of the song, Wàsíu Àyìndé Marshal on the other hand 'prides' the ibà (homage) phenomenon which shows the rich Yorùbá cultural heritage for the high premium placed on respect and homage. It should be mentioned that the high premium placed on respect and homage in Yorùbá cultural heritage distinguishes one as the original and authentic omo ilè káàró oojizire, a metonymy for a thoroughly bred and acculturated child.

Still on aesthetics, the main thrust of Yorùbá contemporary song is that it touches on the beauty of African cultural heritage as opposed to the ethnophobic bias which the Europeans has for it and which was overtly displayed in Joseph Conrad's 1987 'Heart of Darkness'. These contemporary songs do not just extol the social relevance of the art; they also punctured the notion of 'art for art sake' by educating, entertaining, teaching and prescribing the way for a chaos-free society. The songs are wrapped with satire and are garnished with proverbial sayings which are the indigenous tattoos that are embellished in the culture. These indigenous tattoos comment on the dwindling cultural ethos to revive them in the society as it also points to the need to go back to the basis in which the goodliness and order of the society lie and to which the 'omolúàbi' concept foregrounds. This is aptly captured in the excerpt of the lines from Músílíù Hárúnà İshòlá below:

Kò ní burú fún orí

K'ádé filà s'órikún ẹsè

Ęnu wọn mèfà

Equ won mèje 
Àwa ò bá ẹlénu méjì seré mó

Báa lá ò ní s'òrò

Òrò á sora è bó bá pé

İgéraga ńse wón

It will not go bad for the head 2ce

That the cap would be worn on the knee

They say six today

They say seven tomorrow

We do not want to play with an inconsistent person.

If we say we would not talk

The truth will come to the fore at its own time

They are boisterous.

While Wàsíù Àyìndé Marshal in 'the truth' intones:

Òrò NEPA kéę bá wa dá si

Bí a se sanwó iná tó

Iná kò sí

You should intervene in NEPA ${ }^{14}$ matter

So much that we pay for electricity

There is no electricity.

From the excerpt above, the forward, inconsistent nature of some certain elements in the society is displayed as their ingenuity is not consistent but questionable. These elements are shaky and they talk with both sides of their mouth. Howbeit though, their antics and cunning ways would soon come to the limelight and their deeds which are boisterous would be seen as such that is detrimental to good orderliness in the society as culturally prescribed. The artist as infotainment uses their creative ability to satirize and cast aspersions on the social problems that prevail in the country. The lampoon is further accentuated by the hopelessness of the elements with which they co-habit with and has become their quintessence counterpart in the society.

Proverb usage in Yorùbá contemporary song serves as a stimulant and a pointer to the right order in the society. Through its use of parodies, puns and acoustic wordplay, it presses on the need for intelligence and smartness

14 NEPA is the acronym for the Power Generating Company in Nigeria. Its full meaning is National Electric Power Authority. The name has however been changed to Power Holding Company of Nigeria (PHCN). 
as it abhors sluggishness or slothfulness in society. Wàsíu Àyìndé Marshal in pointing to the right order in the society in his song intones:

Òrò Nigeria la fé șo

Kéę wá gbó

War Against Indiscipline ${ }^{15}$

Ó dáa ká á gbà á

Ká fi k'ógbón

Ibi kíbi t'áa bá wà

War Against Indiscipline

Káá ș'òtító

Indiscipline

Wón ní ká a máá șe mó

Wón ní ká á ṣ’òtitó

We want to talk about Nigeria

Come and hear

War Against Indiscipline

It is good that we take it

That we learn from it

Wherever we are

War against Indiscipline

We should be truthful

Indiscipline

They said we should not do it again

They said we should be truthful.

The parodies in the above lines are in the words ó dáa ká á gbà á (it is good that we take it), ká fi k'ógbón (that we learn from it) and káá ș'otitó (we should be truthful). The malaise that the military sees as a clog in the wheel of progress of the country and sets to wash away incidentally serves as the defining nuance of the same military! The clampdown on corruption and other vices by the then Government in power became 'repressive' even within the military and this is not surprising when General Ibrahim Badamosi Babangida (IBB) in a palace coup on August $27^{\text {th }}, 1985$ took over power to become the Head of State in Nigeria. If the tempo has been sustained, the malaise called corruption that has bedevilled the Nigerian state to this comatose level

15 War Against Indiscipline (WAI) was introduced in Nigeria by the military dictatorship regime of General Muhammadu Buhari/Tunde Idiagbon in March 1994. It was a mass mobilization program organized by the military junta to correct social maladjustments and curb all forms of corruption both in public and private places. 
would have been nipped in the bud and curbed! The nation would not have been a caricature before the comity of nations.

In the track, 'My Dear' by Músílíù Hárúnà İshòlá, an example of parody, jokes and wordplay is aptly displayed:

Wo, fine girl dúró náa

Kílo sé e tí o ńfi mí pa sáyó?

Mò ńpè é, ò ń show...

Léşèkeşsè là ńpe 'şè

K'éléşè kó gbéşè l'éşè

Lái gbéşè ni ẹleşè fi gbè 'sé kan lójú

Elléşè di ẹlèsè...

Look, fine girl wait

Why are you ignoring me?

I'm calling you but you are making jest of me

Instantly the leg is called

The leg owner is expected to make haste

The inactivity of the leg owner makes it to receive a blow on the face

The leg owner becomes a sinner.

From the lines above, the beauty of Yorùbá language comes to fore in its phonoaesthetic array of the word eléşè (leg owner) and èsè (sin). The same word of the same lexis but with different tonal marks is juxtaposed against each other in an array of wordplay which is rhythmic. This tonal word play is symbolic. In Yorùbá culture, a child's intelligence is built by and tested through unfaltering wordplay. The mastery of the wordplay starts from the home front. Little wonder that a Yorùbá maxim says, 'omo tí ó bá máa jé Àsàfá, kékeré ni ó tii ș'ẹnu șámúṣámá' (a child that would be intelligent would show the traits from infancy). Yorùbá contemporary song uses satire as a parody in drawing out the dangers inherent in slothfulness in society. Through the wordplay, the individual is jeered at as sluggishness often makes one to be unjustly punished. Intelligence and smartness is a value that has a high premium in the traditional society as the inculcation and assimilation of it begins from the home front.

Yorùbá contemporary song serves as social reformers. It achieves this feat through the use of acerbic proverbial sayings to deconstruct the societal values that are ebbing into oblivion. For example, consider these lines by Músílíu Hárúnà İshòlá:

Kétékété bí ó ti ş̧ògá aláàrù tó 
Kò lè gbé gẹdú

Tí ò bá fé wolè

Kò ní jé se irú è

Àfi tí ó bá féfi òrun sè fà

Ni á ní oún fé ru mótò lẹle

As strong as the donkey is than a peon

It cannot carry a timber

If it does not want to be submerged

It will never attempt such

Except it want to die ingloriously

That it will say it want to carry a car.

From the lines above, the need for moderation in human endeavor in society is stressed. The song preaches moderation (ìwòntùn 'wònsi) both in character and indeed. This is one of the principal characters of the 'omolúàbi' belief. It is therefore not surprising that Victor Olanipekun says, "part of the beliefs of the Yorùbá is the view that the very essence of one's life is a good character." ${ }^{16}$ Honesty is a sub-set of good character and this is what Wàsíu Àyìndé Marshal haps on as he asserts:

Wón ní ká a máá șe mó

Wón ní ká á ș'otitó

(They said we should not do it again

They said we should be truthful).

Good character and honesty are social values that have almost lost their significance in our modern-day lives. Yorùbá contemporary song, therefore, serves as the hind leg moving against our cultural denunciation. Furthermore, Olanipekun asserts the Aristotelian ethics which are fundamental core attributes of the (omolúàbi) Yorùbá belief system. The Aristotelian ethics "[being] are justice, honesty, generosity and courage."15 These characteristics when found to be missing in the deeds of an individual or society, lopsidedness and imbalance are bound to exist. The Artists through proverb and parody uses satire as reflected in the songs to cast aspersion as a lampoon and as derision of the deeds of an individual or society. It is to this end that Lawuyi

16 Olanipekun, Victor. "Omọlúàbí: Rethinking the concept of Virtue in Yorùbá Culture and Moral System.” Africology: the Journal of Pan African Studies 10.9 (2017): 221. 
summarizes the discourse that, "moderation should be exercised by a respectable person" (ìwòntùn 'wònsì ló ye omolúàbi). ${ }^{17}$

\section{Conclusion}

As earlier stated that music permeates every aspect of Yorùbá life as there is nothing the Yorùbá do not sing about or turn into song as virtually everything that affects the life of a community significantly can form the subject of these songs. This is so because of the musical nature of the language which is inherent in its tonality and sound system. By sound system, one is talking about the rhythm, the various sound devices associated with the language and its cultural reliance on both tonal wordplay and counterpoint. All these give Yorùbá language its musicality.

Every Artist is a product of the society as s/he shapes and is shaped by society. As a matter of fact, society provides the raw materials which are later refined by the Artists. The fact that the Artists operates within the ambit of society gives him the privilege to interact with society. His interaction with the society to condemn vices and commend virtues precipitates the use of proverbs. The use of proverbs as an indigenous tattoo, however, as a communicative nest is sacrosanct to the Artists as it showcases the uniqueness and dynamism of meanings in the language which has hitherto been dubbed as vilifying. African language is perceived by the Eurocentric critics to be vilifying with its dual nature as the spoken word is believed to express more than what it reveals. That is, it bears more in words and images. Yorùbá contemporary song is highly imagistic and the satire expressed therein is explicit. This is in tandem with the Yorùbá proverbs that, 'l'ówe l'ówe ni à ńlu ilù àgídigbo' (àgídìgbo drum is beaten proverbially) and 'ẹni ègún bá gún l'ésè ní ńse lákànláká to alábe lọ' (whoever the thorn pinches would hop to the doctor for a remedy). Satire is often used proverbially in the songs to foreground a fundamental Yorùbá cultural concept, 'omolúàbi' which is prescriptive. As a reformative tool casts in a language that is easily understood by the society, the essence of proverb usage in the songs is to draw attention to the basis of life in the society and/or individual.

In essence, the use of the indigenous tattoos by the song artists, according to Falola's voice, restores pride, provides the basis of identity, "enhances the struggle to attain mental liberation, and provides the framework for development." 18 This is so as the 'phenomenon' dubbed as culture remains relevant

17 Lawuyi, O.B. "The Tortoise and the Snail: Animal Identities and Ethical issues concerning Political Behaviour among the Yorùbá of Nigeria.” Second Order 1, (1988): 29.

18 Falola, Toyin. The Power of African Cultures. USA: University of Michigan Press, 2003, 64. 
through language usage in the modern era and has to be integrated into all aspects of socio-cultural and economic life. This study reveals that the use of proverbs as indigenous tattoos has elevated both the language of the song Artists to the status of living art of popular communication and their personalities to that of a mystic 'massieur' as there is the need to localize the global issues and globalized the local ones. Doing so would enhance and ensure continuity of the salient aspects of our culture especially the language, which now seems to have lost its potency and rhythm via the social constrictions.

In a nutshell, borrowing should be adaptive and creative and not as an imitator. This is exactly what the indigenous tattoos do in Yorùbá contemporary songs as replicated through the works of the selected song Artists. Músílíu Hárúnà Ìshòlá tacitly captures this well as he succinctly defrays the notion of 'art for art sake' as he uses his song to both educates and entertains. As a contemporary Yorùbá song Artist, he mixes both the local (àpàlà) and global (pop) styles in his kind of music (Àpàlà) to strike a balance in the ever-changing society to have a wider audience and pride of place compared to the old order of his father which sees àpàlà music as the reserve and genre of the aged ones. This feat by him is quite adaptive, innovative and creative. It should be mentioned however that the indigenous tattoos which colors Yorùbá contemporary songs are richly spiced with comparison. This is so as the Yorùbá language thrives on the comparison. The adaptive and creative know-how of the song Artist follows suit from the comparison tenets inherent in the language and this again buttresses the earlier stated point that 'a child that would be intelligent would show the traits from infancy.' In drawing comparison between ecstasy and pain, a woman's response (outburst) to the two is compared as this is aptly captured in the excerpt of the lines from Músílíu Hárúnà Ìshòlá below:

Orí okó ò t'órí omo

èyin elégbé mo ní.

B'óbìnrin jè gbádùn ẹpòn, won á se bó ńké.

Àkólé okó nìyẹ

The penis head is not as big as that of a baby

My retinue of singers.

When a woman enjoys copulation,

One would think she's crying.

That is the penis delight. 
The comparison in the excerpt above is between a woman's action during child's birth (pain) and copulation (ecstasy). The juxtaposition is between the woman's birth canal which takes something as big as a baby's size and also, something smaller but yet, it makes the woman cry. Although the woman cried in the two circumstances but the crying is for different purposes. The adaptive and creative know-how of the song Artist comes to the fore in the song as he talks about two vital things that a woman accommodates in her body and yet, does no harm to the system!

\section{Bibliography}

Adegoju, Adeyemi. "The Musician as Archivist: An Example of Nigeria's Lagbaja." Itupale: Online Journal of African Studies 1 (2009):1-23. http://www.researchgate.net/publication/228375725/The_Musician_as Archivist.

Adeoti, Gbemisola. "The Loudness of the 'Unsaid': Proverbs in Selected African Drama." Legon Journal of the Humanities 30.1 (2019): 82-104. http:// dx.doi.org/10.4314/Ijh.v30i1.4 on January 22, 2021.

Andah, B.W. "African Development." Occasional Publications of the Department of Anthropology, University of Ibadan, 1982, 4-25.

Ayinde-Marshal, Wasiu. "Iba." Àbòdé Méccà. Lagos: Fújì Rẹpẹtẹ Label, 1980. Digital Audio Disc, 33min 46secs.

Ayinde-Marshal, Wasiu. "The Truth." Talazo. Lagos: Ola Oluwa Music Label, 1984. Digital Audio Disc, 34min 38secs.

Falola, Toyin. The Power of African Cultures. USA: University of Michigan Press, 2003.

Finnegan, Ruth. Oral Literature in Africa. Oxford: Clarendon Press, 1970.

Halliday, Michael Alexander.K. On Language and Linguistics, edited by Jonathan Webster, The Collected Works of M.A.K Halliday, vol.3, New York: Continuum, 2003.

Haruna- Ishola, Musiliu. Sóyòyò. 2000. Lagos: Jooat Record, 2003. Digital Audio Disc, 40min 46secs.

Lawuyi, O.B. "The Tortoise and the Snail: Animal Identities and Ethical issues concerning Political Behaviour among the Yorùbá of Nigeria." Second Order 1 (1988): 29-30.

Mabawọnku, 'Funminiyi. "Interplay of Ideology, symbols and culture: A reading of Zulu Sofola's plays." Iroro: A Journal of Arts 18.1\&2 (2019): 36-57.

Ogunba, Oyin. "Literary Art and Literary Creativity in Contemporary Africa." Paper presented at the Inaugural Lecture Series 36, University of Ife. 1978. 1-28. 
Ojaide, Tanure. "Modern African Literature and Cultural Identity." African Studies Review 35.3 (1992): 43-57.

Olanipekun, Victor. "Omọlúàbí: Rethinking the concept of Virtue in Yorùbá Culture and Moral System." Africology: the Journal of Pan African Studies 10.9 (2017): 217-31.

Osani, Dumbi. "The Aesthetics of Proverbs in Nigerian Fiction: D.O Fagunwa and Chinua Achebe." Papers in English and Linguistics 9 (2008): 95-109.

Tracey, Hugh. Chopi Musicians: Their Music, Poetry and Instruments. 1974. Quoted in Oyin Ogunba. "Literary Art and Literary Creativity in Contemporary Africa." Ife: University of Ife, 1978, 11. 
